\title{
Involvement of NF-KB and HSP70 signaling pathways in the apoptosis of MDA-MB-23 I cells induced by a prenylated xanthone compound, $\alpha$-mangostin, from Cratoxylum arborescens [Corrigendum] [Retraction]
}

Ibrahim MY, Hashim NM, Mohan S, et al. Involvement of NF- $\mathrm{KB}$ and HSP70 signaling pathways in the apoptosis of MDA-MB-231 cells induced by a prenylated xanthone compound, $\alpha$-mangostin, from Cratoxylum arborescens [Corrigendum]. Drug Des Devel Ther. 2015;9:3001-3002 was published subsequent to Ibrahim MY, Hashim NM, Mohan S, et al, Involvement of NF-KB and HSP70 signaling pathways in the apoptosis of MDA-MB-231 cells induced by a prenylated xanthone compound, $\alpha$-mangostin, from Cratoxylum arborescens. Drug Des Devel Ther. 2014;8:2193-2211, and Ibrahim MY, Hashim NM, Mohan S, et al, $\alpha$-Mangostin from Cratoxylum arborescens demonstrates apoptogenesis in MCF-7 with regulation of NF-KB and Hsp70 protein modulation in vitro, and tumor reduction in vivo. Drug Des Devel Ther. 2014;8:1629-1647.

When comparing the papers it becomes apparent that they have an unacceptably high degree of similarity and re-use. Further, there is no clear scientific distinction between the cell lines and the results in both. Accordingly, the Editor-in-Chief and Publisher issued a Notice of Retraction for Ibrahim MY, Hashim NM, Mohan S, et al, Involvement of NF-KB and HSP70 signaling pathways in the apoptosis of MDA-MB231 cells induced by a prenylated xanthone compound, $\alpha$-mangostin, from Cratoxylum arborescens. Drug Des Devel Ther. 2014;8:2193-2211 and the subsequent Corrigendum.

\section{Publish your work in this journal}

Drug Design, Development and Therapy is an international, peerreviewed open-access journal that spans the spectrum of drug design and development through to clinical applications. Clinical outcomes, patient safety, and programs for the development and effective, safe, and sustained use of medicines are the features of the journal, which

\section{Dovepress}

has also been accepted for indexing on PubMed Central. The manuscript management system is completely online and includes a very quick and fair peer-review system, which is all easy to use. Visit http://www.dovepress.com/testimonials.php to read real quotes from published authors. 